\title{
Pan evaporation and sensor based approaches of irrigation scheduling for crop water requirement, growth and yield of okra
}

\author{
VIKAS SHARMA ${ }^{*}$, P.K. SINGH ${ }^{1}$, S.R. BHAKAR ${ }^{1}$, K.K. YADAV ${ }^{1}$, S.S. LAKHAWAT ${ }^{2}$ \\ and MANJEET SINGH ${ }^{1}$
}

\author{
${ }^{1}$ Department of Soil Water Engineering, ${ }^{2}$ Department of Horticulture \\ Maharana Pratap University of Agriculture and Technology, Udaipur, India \\ "Corresponding author email : vikassharmaacet@gmail.com
}

\begin{abstract}
The results of this study revealed that the pan evaporation and sensor based irrigation scheduling along with fertigation scheduling significantly affected the plant height, fruit weight, fruit length, crop water requirement, crop yield and water use efficiency of okra crop. The pan evaporation and crop evapotranspiration (ETc) values significantly vary over different stages of okra crop. The maximum and minimum average daily pan evaporation was recorded $8.4 \mathrm{~mm} \mathrm{day}^{-1}$ and 4.5 $\mathrm{mm} \mathrm{day}^{-1}$ at mid stage and late stage of okra crop respectively while, the maximum average daily ETc was recorded $7 \mathrm{~mm}$ day ${ }^{1}$ at mid stage of okra crop. A approach of irrigation scheduling with 100 per cent field capacity, based on soil moisture sensor under automated drip irrigation system along with 100 per cent RDF through fertigation in equal splits at 4 day intervalor 80 $\%$ per cent of volume of crop water requirement based on pan evaporation under automated drip irrigation along with 100 per cent RDF through fertigation in equal splits at 2 day interval, can be used for irrigating okra crop with significant water saving, crop yield and water use efficiency under limited availability of daily weather datain climatic condition of Udaipur district of Rajasthan.
\end{abstract}

Key words: Pan evaporation, crop coefficient, irrigation scheduling, water use efficiency

Nowadays, the sector that consumes the major amount of fresh water in India is agriculture, and due to the limitation and scarcity of fresh water resources, it is necessary to manage irrigation rationally and emphasize on the selection of most appropriate method of irrigation scheduling for irrigating the crops under drip irrigation, so they can work more efficiently, minimizing waste in irrigated agriculture (Farias et al. 2017). Irrigation scheduling remains a very effective technique for applying the required amount of irrigation water at the appropriate time (Munoz-Carpena et al. 2005). The variation in water use efficiency is also resulted from variation in crop yield (Pradhan et al. 2018). An automated irrigation system is integrated with various types of electronic controllers and uses microclimate data to schedule water irrigation in order to save irrigation water and reduce non-pointsource pollution (Nautiyal et al. 2010). The okra (Abelmoschus esculentus L.) is a famous vegetable with more nutritional value, great acceptance in the market and belongs to the Malvaceae family. It is mainly cultivated mainly in tropical regions. The fertigation schedule was significantly influenced the vegetative growth, yield attribute, and quality characters parameters of okra crop (Jamrey et al. 2018). The current trend in such advanced irrigation techniques for conserving water and energy consumed for irrigation in agriculture is to switch from a manual system to automatic operations in a drip irrigation system with appropriate approach of irrigation and fertigation scheduling. The performance of soil moisture sensor based automated irrigation system has been tested for okra crop which shows good correlation between soil moisture by measured by sensor and soil moisture content by gravemetric method (Sharma et al. 2019). A judicious assessment of the water requirement of the crops is crucial for irrigation scheduling and planning of farm irrigation systems (Mushtaq et al. 2020). In view of above discussion, effort was made to assess the impact of various approaches of irrigation scheduling along with fertigation scheduling on growth, crop yield of okra and 
water use efficiency under different irrigation systems in climatic condition of Udaipur district of Rajasthan, India.

\section{MATERIAL AND METHODS}

\section{Study area}

A field experiment was conducted during year 2019 and 2020 at Plasticulture Farm, MPUAT Udaipur, which is situated between $24^{\circ} 35^{\prime} 31.5^{\prime \prime}$ to $24^{\circ} 35^{\prime} 38.5^{\prime \prime}$ North latitude and $73^{\circ} 44^{\prime} 18.2^{\prime \prime}$ to $73^{\circ} 44^{\prime} 21.1^{\prime \prime}$ East longitude at an altitude of 582.17 meters above mean sea level. An average annual rainfall is $637 \mathrm{~mm}$, mostly received during monsoon season (June to September). The study area is characterized by sub humid climate. The soil type was sandy loam. The maximum temperature goes as high as $46^{\circ} \mathrm{C}$ during summer and minimum as low as ${ }^{\circ}{ }^{\circ} \mathrm{C}$ during winter months.

\section{Calculation of crop water requirement}

In this study MAHY-28 variety of okra crop was sown on February 27, 2019 and crop water requirement was calculated by pan evaporation data and soil moisture sensor data on daily basis. The meteorological data such as temperature, relative humidity, wind speed, rainfall, pan evaporation and sunshine hours during the crop period was acquired from the meteorological observatory located at Instructional Farm, , Udaipur. The crop evapotranspiration $\left(\mathrm{ET}_{\mathrm{c}}\right.$ ) was calculated separately from pan evaporation $\left(\mathrm{E}_{\mathrm{Pan}}\right)$, pan coefficient with the help of crop coefficient $\left(\mathrm{K}_{\mathrm{c}}\right)$ (equation 1 ) at every stage of crop growth. The crop coefficient, Kc values of okra crop for Udaipur region (Anon., 2019) was taken (Table 1).The pan coefficient $\left(\mathrm{K}_{\mathrm{p}}\right)$ for calculating crop evapotranspiration by using pan evaporation data was taken as 0.7. Further the estimation of crop water requirement during whole period of okra crop was done by using equation 2 , for fixation of irrigation scheduling of okra crop under drip irrigation for Udaipur region.

$$
\begin{gathered}
\mathrm{ET}_{\mathrm{C}}=\mathrm{E}_{\mathrm{pan}} \times \mathrm{K}_{\mathrm{p}} \times \mathrm{K}_{\mathrm{C}} \\
\mathrm{V}=\sum(\mathrm{Ep} \times \mathrm{Kp} \times \mathrm{Kc} \times \mathrm{Sp} \times \mathrm{Sr} \times \mathrm{WP}+\mathrm{ER})
\end{gathered}
$$

\section{Where,}

$\mathrm{V}=$ estimated crop water requirement at $100 \%$ water use scheduling, litre/day/plant, Epan = Pan Evaporation, mm, $\mathrm{Kp}=$ Pan coefficient, $\mathrm{Kc}=$ Crop coefficient, $\mathrm{Sp}=$ Plant to plant spacing, $\mathrm{m}, \mathrm{Sr}=$ Row to row spacing, $\mathrm{m}, \mathrm{Wp}=$ Percentage wetted area, 90\%, ER = Effective rainfall, $\mathrm{mm}$

In this study, based on USDA S.C.S method the effective rainfall (ER) was calculated by on monthly basis by following equation:

$$
\mathrm{ER}=\mathrm{P}_{\mathrm{t}}\left[\frac{125-0.2 \times \mathrm{Pt}}{125}\right] \text { for } \mathrm{Pt}<250 \mathrm{~mm}
$$

Where, $\mathrm{P}_{\mathrm{t}}$ - total rainfall, $\mathrm{mm}$

In sensor based treatments, soil moisture sensor which works on resistivity principle, transmits the real data of soil moisture content to microcontroller and irrigation event take place automatically as per availability of moisture content with respect to predefine value stored in data base of controller for irrigation scheduling i.e. field capacity (FC) which is taken as 31 per cent on volume basis.

\section{Method of sowing and fertigation scheduling}

In this experiment okra seeds were directly sown on $27^{\text {th }}$ of February for both years (2019 and 2020) with the plant spacing $15 \mathrm{~cm}$ and row spacing of $50 \mathrm{~cm}$ on all treatments (Table 2) with three replications. In this study FYM@250 q ha ${ }^{-1}$ was applied during land preparation. Recommended dose of Fertilizer (RDF) N:P:K, 60:30:30 $\mathrm{kg} \mathrm{ha}^{-1}$ were supplied for both years. In this study the $40 \%$ and $60 \%$ of RDF were applied during initial plus development stage and mid stage of crop growth respectively, through fertigation in different treatment (excepttreatment $\mathrm{T}_{6}$ ) as per fertigation scheduling.

\section{Crop observation}

The plant height of selected plants for each treatment was recorded at 30 days interval and at harvest in all replication. The total weight of ten fruits was recorded at the time of each harvesting for each treatment in all replications and then average weight of fruit was calculated. The lengths of ten fruits were recorded at the time of each harvesting for each treatment in all replications 
Table 1: Crop coefficient for okra crop for Udaipur region

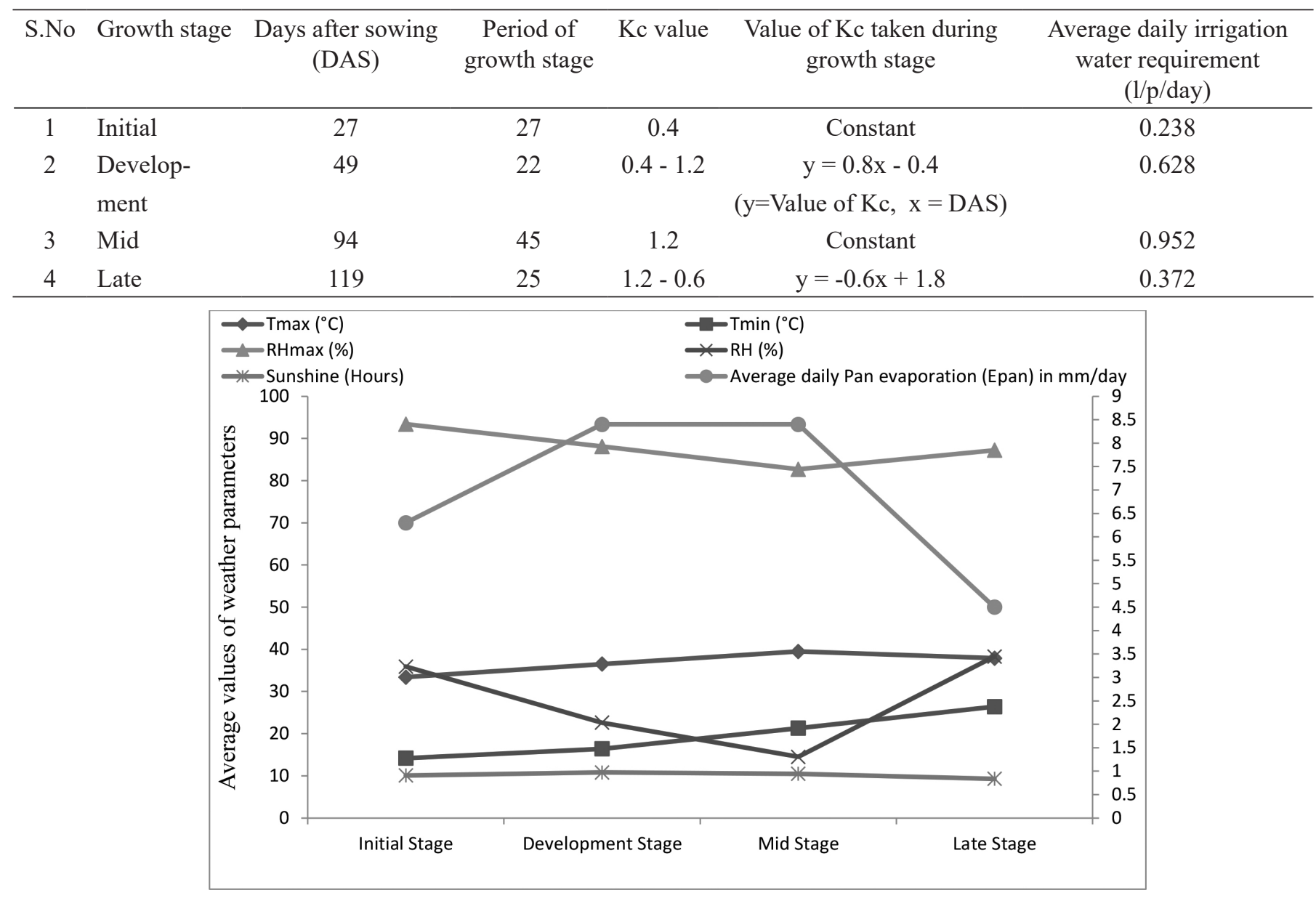

Fig. 1: Average daily value of weather parameters growth stage of okra crop

and then average length of fruit was carried out. The yield of fruits per plot $(\mathrm{kg})$ was weighed separately at the time of each harvesting for each treatment in all replications and then it was converted in to total yield of fruits per hectare $\left(\mathrm{t} \mathrm{ha}^{-1}\right)$.

\section{Water use efficiency}

Water use efficiency is defined as the ratio of grain yield to the total depth of irrigation. It was calculated by equation 3 (Singh et al., 2019).

$$
\begin{gathered}
\text { Field water use } \\
\text { efficiency }(\%)=
\end{gathered} \quad \begin{gathered}
\text { Crop yield (tha) } \\
\text { Total depth of irrigation }(\mathrm{mm})
\end{gathered} \text { x100 }
$$

\section{RESULTS AND DISCUSSION}

The result obtained from pooled daily weather data during year 2019 and 2020 indicated that during initial stage, average daily value of $\mathrm{T}_{\max }$ and $\mathrm{T}_{\min }$ was found to be lowest, whereas $\mathrm{RH}_{\max }$ was found to be highest with a value of 93.8 percent as compared to remaining growth stage. The Fig. 1 shows that the average daily value of sunshine hour was almost linear during all growth stage. The maximum and minimum average daily pan evaporation was recorded $8.4 \mathrm{~mm}^{\text {day }}{ }^{-1}$ and $4.5 \mathrm{~mm}_{\text {day }}{ }^{-1}$ at mid stage and late stage of okra crop respectively. It results maximum irrigation water requirement as $0.952 \mathrm{l} /$ plant/day on daily average basis for the okra crop during mid stage (Table 1). It is mainly due to high atmospheric temperature as well as average daily pan evaporation at mid stage (Fig 1) and there is only negligible availability of effective rainfall during $(28.8 \mathrm{~mm})$ at late stage of okra crop. The temporal variation in average daily weather data play an important role in deciding the application of appropriate amount of irrigation water as well as appropriate time of irrigation (i.e irrigation scheduling) during whole growing period of okra. 
Table 2: Details of treatments for irrigation and fertigation scheduling of okra crop

\begin{tabular}{|c|c|}
\hline $\mathrm{T} 1$ & $\begin{array}{l}100 \% \text { Field Capacity (FC), based on soil moisture sensor under automateddrip irrigation (ADI) with } 100 \% \mathrm{RDF} \\
\text { through fertigation in equal splits at } 2 \text { day interval }\end{array}$ \\
\hline $\mathrm{T} 2$ & $\begin{array}{l}80 \% \text { Volume of crop water requirement based on Pan Evaporation (Epan) under ADI with } 100 \% \text { RDF through ferti- } \\
\text { gation in equal splits at } 2 \text { day interval }\end{array}$ \\
\hline T3 & $\begin{array}{l}100 \% \mathrm{FC} \text {, based on soil moisture sensor under ADI with } 100 \% \text { RDF through fertigation in equal splits at } 4 \text { day } \\
\text { interval }\end{array}$ \\
\hline T5 & $\begin{array}{l}100 \% \text { Volume of crop water requirement based on Epan under conventional (manual) drip irrigation with } 100 \\
\% \text { RDF through fertigation in equal splits at } 6 \text { day interval }\end{array}$ \\
\hline T6 & $50 \%$ depletion in FC, under flood irrigation with $100 \%$ RDF through farmer's practice (control) \\
\hline
\end{tabular}

Table 3: Average plant height $(\mathrm{cm})$ of okra crop at different days after showing (DAS) and at harvest

\begin{tabular}{cccc|ccc|cccc|ccc}
\hline & \multicolumn{3}{c}{ 30 DAS } & \multicolumn{3}{c}{60 DAS } & \multicolumn{3}{c}{ A0 DAS harvest } \\
\cline { 2 - 13 } & 2019 & 2020 & Pooled & 2019 & 2010 & Pooled & 2019 & 2020 & Pooled & 2019 & 2020 & Pooled \\
\hline $\mathrm{T}_{1}$ & 16.1 & 14.7 & 15.4 & 46.2 & 42.8 & 44.5 & 79.6 & 77.0 & 78.3 & 90.2 & 89.0 & 89.6 \\
$\mathrm{~T}_{2}$ & 13.0 & 12.6 & 12.8 & 37.4 & 35.7 & 36.5 & 73.7 & 66.2 & 69.9 & 82.7 & 81.8 & 82.2 \\
$\mathrm{~T}_{3}$ & 12.9 & 12.4 & 12.6 & 39.3 & 38.1 & 38.7 & 92.6 & 90.5 & 91.5 & 104.8 & 102.3 & 103.5 \\
$\mathrm{~T}_{4}$ & 12.0 & 11.9 & 11.9 & 33.7 & 31.7 & 32.7 & 71.4 & 64.4 & 67.9 & 81.2 & 80.3 & 80.7 \\
$\mathrm{~T}_{5}$ & 12.5 & 12.4 & 12.4 & 36.0 & 34.2 & 35.0 & 69.1 & 65.4 & 67.2 & 80.7 & 80.0 & 80.3 \\
$\mathrm{~T}_{6}$ & 11.3 & 10.6 & 10.9 & 28.6 & 27.0 & 27.8 & 68.4 & 59.6 & 64.0 & 76.7 & 73.5 & 75.1 \\
$\mathrm{SEM}$ & 0.25 & 0.20 & 0.22 & 1.37 & 0.45 & 0.91 & 1.49 & 0.30 & 0.89 & 1.39 & 1.50 & 1.44 \\
$\mathrm{CD}<5 \%$ & 0.74 & 0.70 & 0.72 & 4.14 & 1.35 & 2.74 & 4.49 & 0.90 & 2.69 & 4.20 & 4.50 & 4.35 \\
$\mathrm{CV}(\%)$ & 3.77 & 3.70 & 3.73 & 7.43 & 2.57 & 5.00 & 3.93 & 0.80 & 2.36 & 3.24 & 3.50 & 3.37 \\
\hline
\end{tabular}

\section{Effect on plant height of okra crop}

The data related to plant height of okra at different days after sowing during year 2019 and 2020 are summarized in Table 3. The polled data analysis revealed that the plant height at 30 and 60 DAS were found highest in treatment $\mathrm{T}_{1}$ followed by treatments $\mathrm{T}_{2}$ and $\mathrm{T}_{3}$ at 30 and 60 DAS, respectively. While the plant height at 90 DAS and at time of harvest were recorded maximum in treatment $\mathrm{T}_{3}$ followed by treatments $\mathrm{T}_{1}$. The minimum plant height at all stages of crop was recorded in treatment $\mathrm{T}_{6}$, in which fertigation takes place as per farmer practice under flood irrigation. The plant height at 30 and 60 DAS was found highest in treatment $T_{1}$ because in this treatment large number of fertigation split takes place during initial and development stage of okra crop as per fertigation scheduling, which result more availability of nutrient during these stages as compared to all remaining treatment. Whereas, under treatment having fertigation in equal splits through water soluble chemical fertilizers at 4 day interval, nutrient supplied through continuous fertigation till mid stage of crop growth which resulting continuous availability of nutrient for plant and minimum fertigation stress during mid and late stage for higher plant height. These results are in conformity with the findings of Venkadeswaran et al. (2014). The highest plant height at all stages was recorded maximum in those treatments, in which irrigation takes place on the basis of soil moisture sensor under automated drip irrigation system which maintained moisture content at field capacity near the effective plant root zone of okra and minimum leaching of fertilizer through irrigation water as compared to flood irrigation. The other research confirms that heights of rose plant controlled by a computer program for automatic watering were slightly higher than those manually irrigated (Wen-jin et al., 2010). 
Table 4: Average weight and length of okra fruit at harvest

\begin{tabular}{ccccccc}
\hline \multirow{2}{*}{ Treatment } & \multicolumn{3}{c}{ Average weight of fruit $(\mathrm{gm})$} & \multicolumn{3}{c}{ Average length of fruit $(\mathrm{cm})$} \\
\cline { 2 - 7 } & 2019 & 2020 & Pooled & 2019 & 2020 & Pooled \\
\hline $\mathrm{T}_{1}$ & 10.7 & 9.8 & 10.2 & 14.1 & 13.9 & 14.1 \\
$\mathrm{~T}_{2}$ & 10.1 & 9.6 & 9.8 & 13.3 & 12.7 & 13.0 \\
$\mathrm{~T}_{3}$ & 12.7 & 12.0 & 12.3 & 15.6 & 16.6 & 16.2 \\
$\mathrm{~T}_{4}$ & 10.0 & 10.0 & 10.0 & 13.4 & 13.5 & 13.5 \\
$\mathrm{~T}_{5}$ & 9.7 & 9.9 & 9.8 & 11.3 & 10.2 & 10.8 \\
$\mathrm{~T}_{6}$ & 9.0 & 9.0 & 9.0 & 11.8 & 10.5 & 11.2 \\
$\mathrm{SEM}$ & 0.5 & 0.7 & 0.6 & 0.5 & 0.6 & 0.6 \\
$\mathrm{CD}<5 \%$ & 1.5 & 2.1 & 1.8 & 1.4 & 1.9 & 1.7 \\
$\mathrm{CV}(\%)$ & 9.7 & 13.5 & 11.6 & 7.2 & 9.8 & 8.5 \\
\hline
\end{tabular}

Table 5: Water requirement, yield and water use efficiency of okra under different scheduling of irrigation

\begin{tabular}{|c|c|c|c|c|c|c|c|c|c|c|c|c|c|c|c|c|c|c|}
\hline \multirow[t]{2}{*}{ Treatment } & \multicolumn{3}{|c|}{$\begin{array}{l}\text { Total irrigation water } \\
\text { applied }(\mathrm{mm})\end{array}$} & \multicolumn{3}{|c|}{$\begin{array}{l}\text { Effective rainfall } \\
\qquad(\mathrm{mm})\end{array}$} & \multicolumn{3}{|c|}{ Crop water requirement } & \multicolumn{3}{|c|}{$\begin{array}{c}\text { Total water saving } \\
\text { over } \mathrm{T}_{6}(\%) \\
\text { (Including effective } \\
\text { rainfall) } \\
\end{array}$} & \multicolumn{3}{|c|}{ Crop yield $\left(\mathrm{t} \mathrm{ha}^{-1}\right)$} & \multicolumn{3}{|c|}{$\begin{array}{l}\text { Water use efficiency } \\
\qquad\left(\mathrm{t} \mathrm{ha} \mathrm{a}^{-1}-\mathrm{cm}\right)\end{array}$} \\
\hline & 2019 & 2020 & Pooled & 2019 & 2020 & Pooled & 2019 & 2020 & Pooled & 2019 & 2020 & Pooled & 2019 & 2020 & Pooled & 2019 & 2020 & Pooled \\
\hline $\mathrm{T}_{1}$ & 501 & 356 & 428.5 & 24 & 33.6 & 28.8 & 525.0 & 389.7 & 457.3 & 48.4 & 61.2 & 54.8 & 8.8 & 7.3 & 8.0 & . 168 & . 187 & 0.177 \\
\hline $\mathrm{T}_{2}$ & 619 & 487 & 553.0 & 24 & 33.6 & 28.8 & 643.0 & 520.7 & 581.8 & 36.9 & 48.2 & 42.5 & 7.1 & 5.6 & 6.3 & .110 & .108 & 0.109 \\
\hline $\mathrm{T}_{3}$ & 501 & 356 & 428.5 & 24 & 33.6 & 28.8 & 525.0 & 389.7 & 457.3 & 48.4 & 61.2 & 54.8 & 11.0 & 8.6 & 9.8 & .210 & .221 & 0.215 \\
\hline $\mathrm{T}_{4}$ & 619 & 487 & 553.0 & 24 & 33.6 & 28.8 & 643.0 & 520.7 & 581.8 & 36.9 & 48.2 & 42.5 & 6.8 & 4.9 & 5.8 & .106 & .094 & 0.100 \\
\hline $\mathrm{T}_{5}$ & 774 & 609 & 691.5 & 24 & 33.6 & 28.8 & 798.0 & 642.7 & 720.3 & 21.6 & 36.1 & 28.8 & 7.0 & 5.9 & 6.4 & .088 & .092 & 0.090 \\
\hline & 995 & 972 & 983.5 & 24 & 33.6 & 28.8 & 1019.0 & 1005.7 & 1012.3 & & & & 5.1 & 4.1 & 4.6 & .050 & .041 & 0.045 \\
\hline $\mathrm{CD}(\mathrm{P}<0.5)$ & & & & & & & & & & & & & 0.4 & 0.4 & 0.4 & & & \\
\hline $\operatorname{SEM}( \pm)$ & & & & & & & & & & & & & 1.2 & 1.2 & 1.2 & & & \\
\hline CV (\%) & & & & & & & & & & & & & 10.4 & 12.6 & 11.5 & & & \\
\hline
\end{tabular}

\section{Effect on average weight and length of okra fruit}

The data related to average weight and length of okra fruit at the time of harvesting during year 2019 and 2020 are summarized in Table 4 . The results of pooled data of both years shows that the average weight and length of okra fruit were found highest in treatment $\mathrm{T}_{3}(100 \%$ $\mathrm{FC}$, based on soil moisture sensor under automateddrip irrigation with $100 \%$ RDF through fertigation in equal splits at 4 day interval) with values of $12.3 \mathrm{gm}$ and $16.2 \mathrm{~cm}$ respectively followed by treatment $T_{1}$ with values of 10.2 gm and $14.1 \mathrm{~cm}$, respectively. While the results obtained from treatment $\mathrm{T}_{4}$ (in which irrigation scheduling based on $80 \%$ of daily pan evaporation data under automated drip irrigation system) on par with result obtained from treatment $T_{1}$ which indicate good results for adoption of deficit pan evaporation based irrigation scheduling under drip irrigation. The minimum values of average weight and length of okra fruit were recorded under treatment $\mathrm{T}_{6}$ in which fertigation takes place as per farmer practice under flood irrigation. Mahendran et al. (2011) also observed higher fruit length, and weight with application of $100 \%$ NPK fertigation through water soluble fertilizers over fertigation as per farmer's practice in okra. It is probably due to that under flood irrigation, large amount of irrigation water wastage through deep percolation, evaporation and conveyance losses as compared to sensor based irrigation automated drip irrigation as well as conventionaldrip irrigation system.

\section{Effect on yield and water use efficiency of okra crop}

The data related to total amount of water applied, 
crop yield and water use efficiency of okra under different scheduling of irrigation are summarized in Table 5. The results of obtained from analysis of polled data of both years shows that minimum amount of total irrigation water applied to the okra crop was recorded for treatments having soil moisture sensor based irrigation scheduling under automated drip irrigation with a value of 428.5 $\mathrm{mm}$. While maximumCrop water requirement was recorded under conventional/flood irrigation treatment with a value of $1012.3 \mathrm{~mm}$. The result shows that soil moisture sensor based irrigation scheduling under automated drip irrigation system save 54.8 per cent total amount of water applied to okra crop over flood irrigation. The crop yield and water use efficiency were also recorded highest under treatment $\mathrm{T}_{3}$ with values of $9.8 \mathrm{t} \mathrm{ha}^{-1}$ and $0.215 \mathrm{t} \mathrm{ha}^{-1}-\mathrm{cm}$ respectively. Similar trend was reported by Michael D. Dukes et al. (2007) for crop yield and WUE of bell pepper crop. The minimum crop yield and water use efficiency were recorded under treatment $\mathrm{T}_{6}$ with values of $4.6 \mathrm{t} \mathrm{ha}^{-1}$ and $0.045 \mathrm{t} \mathrm{ha}^{-1}-\mathrm{cm}$ respectively. It is probably due to that under soil moisture sensor based irrigation scheduling under automated drip irrigation system, water is supplied preciously as well as continuously as per crop need to maintain field capacity, which results optimum availability soil moisture content specially in water scared month (i.e May and June)for the okra crop. The less amount of water loss due to infiltration, seepage, evaporation and over wetting of plant root zone, take place in sensor based automated drip irrigation to enhance water saving, water use efficiency and crop yield over flood irrigation for okra crop. Jaybhaye and Mukherjee. (2020) reported that water saving measures can reduce the evaporation loss and thereby increase the effective utilization of root zone water towards crop production. Our results for WUE are reinforced by Munoz-Carpena et al. (2005) who reported that, automated irrigation systems based on crop water needs can maximize water use efficiency. The results also indicated that crop growth, water saving, crop yield and WUE were much higher in treatments having pan evaporation based irrigation scheduling over flood irrigation.

\section{CONCLUSIONS}

The overall results of this study revealed that the pan evaporation and sensor based irrigation scheduling under automated and conventional drip irrigation system significantly affected the plant growth, crop yield and water use efficiency of okra crop. The plant height, fruit weight, fruit length, crop yield and water use efficiency were found maximum with values of $103.5 \mathrm{~cm}, 12.3 \mathrm{gm}$, $16.2 \mathrm{~cm}, 9.8 \mathrm{t} \mathrm{ha}^{-1}$ and $0.215 \mathrm{t} \mathrm{ha}^{-1}-\mathrm{cm}$ respectively under the treatment $\mathrm{T}_{3}$ in which irrigation takes place on 100 per cent field capacity, based on soil moisture sensor under automated drip irrigation along with 100 per cent Recommended dose of fertilizer through fertigation in equal splits at 4 day interval while, minimum for treatment under flood irrigation along with fertigation as per farmer's practices. However, in case of pan evaporation based irrigation scheduling pooled value of highest crop yield $\left(6.4 \mathrm{t} \mathrm{ha}^{-1}\right)$ was recorded in treatment $\mathrm{T}_{5}$ under conventional drip which were at par with treatment $\mathrm{T}_{2}(6.3$ $\left.\mathrm{t} \mathrm{ha}^{-1}\right)$ with less water applied. So, the study concluded that, under limited availability of daily weather data for calculating crop water requirement of okra, an approach of irrigation scheduling with 100 per cent field capacity, based on soil moisture sensor under automated irrigation system along with 100 per cent RDF through fertigation in equal splits at 4 day interval or 80 per cent of Volume of crop water requirement based on pan evaporation under automated drip irrigation along with $100 \%$ RDF through fertigation in equal splits at 2 day interval could save substantial irrigation water without reducing growth and yield of okra as compared to flood irrigation in climatic condition of Udaipur district of Rajasthan.

\section{ACKNOWLEDGMENTS}

The authors wish to acknowledge the technical and data support from the Incharge of Plasticulture Farm, Department of Agrometeorology MPUAT, Udaipur. Authors also put into record the deep appreciation to Dr. Ajay Kumar Sharma, Dean, CTAE, Udaipur for his immense financial support for conducting this field experiment.

Conflict of Interest Statement: The author(s) declare(s) that there is no conflict of interest.

Disclaimer: The contents, opinions, and views expressed in the research article published in the Journal of 
Agrometeorology are the views of the authors and do not necessarily reflect the views of the organizations they belong to.

Publisher's Note: The periodical remains neutral with regard to jurisdictional claims in published maps and institutional affiliations.

\section{REFERENCES}

Anonymous. (2019). Farmer bulletin, Maharana Pratap University of Agriculture and Technology, Udaipur, India.

Farias, D.B., Lucas, A.A., Araujo, R., Freitas, M. and Jesus, T. (2017). Efficiency in water use and yield of okra in response to different level of irrigation. Rev Br Agr. Irr., 11: 1732-1737.

Jamrey, P.K., Purohit, R.C., Lakhawat, S.S. and Kothari M.K. (2018). Effect of fertigation scheduling on growth and yield of Okra. Eco. Env. Con., 20:511-517.

Jaybhaye, P and Mukherjee, A. (2020). Impact of water saving techniques on leaf water potential of broccoli under various water stress conditions. $J$. Agrometeorol., 22: 535-540.

Mahendran, P. P., Arulkumar, D., Gurusamy, A. and Kumar, V. (2011). Performance of nutrient sources and its scheduling on hybrid bhendi under drip fertigation system. 8th International Microirrigation Congress under 21st International Congress on Irrigation and Drianage, 16-21 October 2011, Tehran, Iran.

Michael, D., Carpena, M., Zotarelli, L. and Scholberg, J.M. (2007). Soil moisture-based irrigation control to conserve water and nutrients under dripIrrigated vegetable production. Agricultural and Biological Engineering Department, University of Florida.

Munoz-carpena, R. and Dukes, M. (2005). Automatic irrigation based on soil moisture for vegetable crops. Extension Bull., ABE356 of the Dept of Agricultural and Biological Engineering,
University of Florida, Gainesville.

Mushtaq, R., Sharma, M.K., Ahmad, A., Krishna, B., Mushtaq, K. and Mir, J.I. (2020). Crop water requirement estimation using pan evaporimeter for high density apple plantation system in Kashmir region of India. J. Agrometeorol., 22: 86.88 .

Nautiyal, M., Grabow, G., Miller, G. and Huffman, R. (2010). Evaluation of two smart ir rigatio $\mathrm{n}$ technologies in Cary, North Carolina. ASABE Annual International Meeting, 20-23 June 2010, Pittsburgh, Pennsylvania.

Pradhan, S., Sehgal, V.K., Sahoo, R.N., Bandyopadhyay, K.K., and Singh, R. (2018). Yield, water and radiation use efficiency of wheat (Triticum aestivum L.) as influenced by irrigation levels in a semi-arid environment. J. Agrometeorol., 20: 31-36.

Sharma, V., Singh, P.K., Bhakar, S.R., Yadav, K.K. and Lakhawat, S.S. (2019). Integration of Soil Moisture Sensor Based Automated Drip Irrigation System for Okra Crop, Int. J. Pure. Appl. Biosc., 7: 277-282.

Singh, P.K., Srivastava, P.C., Sangavi, R., Gunjan, P. and Sharma, V. (2019). Rice water management under drip irrigation: an effective option for high water productivity and efficient zinc applicability. Pantnagar J. Res., 17: 19-25

Venkadeswaran, E., Sundaram, V. and Sankar, R. (2014). Influence of trickle fertigation on growth and physiological attributes of hybrid okra [Abelmoschus esculentus (L.) Moench]. Asian. J. Hort., 2: 347-351.

Wen-jin, Y., Ryo, K., Katsuhiko, K., Lian-hua, L and Hirokazu, K. (2010). A Computer program for automatic watering based on potential evapotranspiration by Penman method and predicted leaf area in miniature pot rose production. Agric. Sci. China., 9: 370-377. 